\title{
Studi Fenomenologis : Perilaku adaptif karyawan lembaga keuangan mikro dimasa pandemi
}

\author{
Dhiyan Septa Wihara \\ Fakultas Ekonomi dan Bisnis Universitas Nusantara PGRI Kediri \\ email: dhiyansepta@unpkediri.ac.id
}

Kata kunci:

Perilaku Adaptif Karyawan

Protocol Covid

Lembaga Keuangan Mikro

\section{Keywords:}

Adaptif Behaviour of Employee

Covid Protocol

Microfinance Institutions

Dhiyan Septa Wihara (2020)

Studi Fenomenologi : Perilaku

Adaptif Karyawan Lembaga

Keuangan Mikro di Masa Pandemi. .

Akuntabilitas: Jurnal Ilmiah Ilmu-

Ilmu Ekonomi, 13(2), 14-29

\begin{abstract}
ABSTRAK
Penelitian ini bertujuan untuk mengkaji dan menganalisis secara mendalam perilaku adaptif karyawan lembaga keuangan mikro khususnya BPR (Bank Perkreditan Rakyat) dan Koperasi dimasa pandemi covid-19. Perilaku adaptif ini dibagi menjadi 4 yaitu membangun komunikasi dengan nasabah, membiasakan diri dengan kondisi baru, bersosialisasi dan bergaul dengan masyarakat, terus bergerak memenuhi target. Studi fenomenologi digunakan karena data ini berasal dari pengalaman partisipan yang saat ini juga sebagai pimpinan aktif dilembaga keuangan mikro.Penelitian ini menggunakan 2 partisipan yaitu pimpinan cabang BPR dan manajer koperasi simpan pinjam yang keduanya memiliki pengalaman puluhan tahun dilembaga keuangan mikro. Temuan penelitian menunjukkan bahwa cara adaptasi ditengah pandemi untuk melakukan penagihan adalah dengan merubah penampilan dengan tidak memakai seragam dan sepatu ketika berkunjung ke nasabah. Kemudian karyawan juga harus membiasakan diri untuk menerapkan protocol covid dalam bekerja. Kantor menyediakan sarana cuci tangan dan handsanitazer untuk nasabah dan karyawan, ini nantinya sudah harus dibiasakan. Pelaporan hasil kinerja keatasan dilakukan setiap bulan sekali namun kebijakan untuk karyawan difokuskan pada aktivitas penagihan karena untuk mengurangi resiko.
\end{abstract}

\section{ABSTRACT}

This study aims to examine and analyze in depth the adaptive behavior of employees of microfinance institutions, especially rural banks and cooperatives during the Covid-19 pandemic. This adaptive behavior is divided into 4, namely building communication with customers, getting used to new conditions, socializing and getting along with the community, continuing to move to meet targets. The phenomenological study is used because this data comes from the experience of participants who are currently active leaders in microfinance institutions. This study used 2 participants, namely the head of the BPR branch and the manager of a savings and loan cooperative, both of whom have decades of experience in microfinance institutions. The research findings show that the way to adapt in the midst of a pandemic to collect is by changing your appearance by not wearing uniforms and shoes when visiting customers. Then employees must also familiarize themselves with implementing the Covid protocol at work. The office provides hand washing facilities and handsanitazers for customers and employees, and this will have to be used later. Reporting on the results of performance limitations is carried out once a month but the policy for employees is focused on billing activities because it is to reduce risk. 


\section{PENDAHULUAN}

Setiap lembaga keuangan pasti memiliki fungsi intermediasi yaitu sebagai perantara keuangan pada masyarakat. Intermediasi disini merujuk pada Undangundang No 10 tahun 1998 tentang perbankan yaitu sebagai badan usaha yang menghimpun dana dari masyarakat dalam bentuk simpanan dan menyalurkannya kepada masyarakat dalam bentuk kredit dan atau bentuk-bentuk lainnya dalam rangka meningkatkan taraf hidup masyarakat.Tidak terkecuali lembaga keuangan mikro seperti koperasi dan Bank perkreditan rakyat (BPR) yang justru memiliki peran penting untuk menggerakkan roda perekonomian daerah melalui aktivitas ekonomi di pedesaan maupun pinggiran kota. Namun ternyata BPR maupun koperasi simpan pinjam tidak bermain sendirian dalam ekspansi kredit mikro. Bank umum konvensional ternyata juga membidik pangsa pasar tersebut. Melalui kredit usaha rakyat (KUR) dengan suku bunga yang sangat rendah tentu akan menjadi daya tarik tersendiri bagi pelaku usaha mikro.sehingga persaingan di sektor mikro pun tidak terelakkan. Lembaga keuangan mikro harus bekerja estra keras untuk tetap mendapatkan perhatian dari nasabah potensial yaitu pelaku usaha disektor mikro termasuk UMKM (Usaha mikro kecil dan menengah). Salah satu strategi yang biasa digunakan adalah "jemput bola" yaitu karyawan lembaga keuangan mikro mendatangi nasabah dan melakukan pembinaan untuk memantau perkembangan usahanya setelah kredit diberikan. Ini merupakan keunggulan yang dipakai sejak dulu dan menjadi pembeda dari bank umum. Dapat dikatakan bahwa ini juga merupakan perilaku adaptif dari karyawan dalam hal pelayanan. Perilaku adaptif menurut Cook et al (2014) adalah kemampuan untuk menyesuaikan diri dengan situasi yang baru serta memiliki ketrampilan akrab dalam situasi tersebut.

Penelitian Yuniarti (2011) menyimpulkan bahwa agar mampu bersaing dengan bank umum maka BPR harus, 1) beroperasi dekat dengan UMKM, 2) hubungan petugas BPR dengan UMKM harus kuat, 3) BPR harus memiliki karakter khusus. Ketiga hal ini merupakan sebenarnya merupakan ciri khas lembaga keuangan mikro termasuk BPR dan koperasi. Namun dimasa pandemi ini ada kendala teknis dilapangan karena dampak kebijakan sosial dan physical distancing 
dari pemerintah yaitu lembaga keuangan mikro dilarang memasuki wilayah padat penduduk.

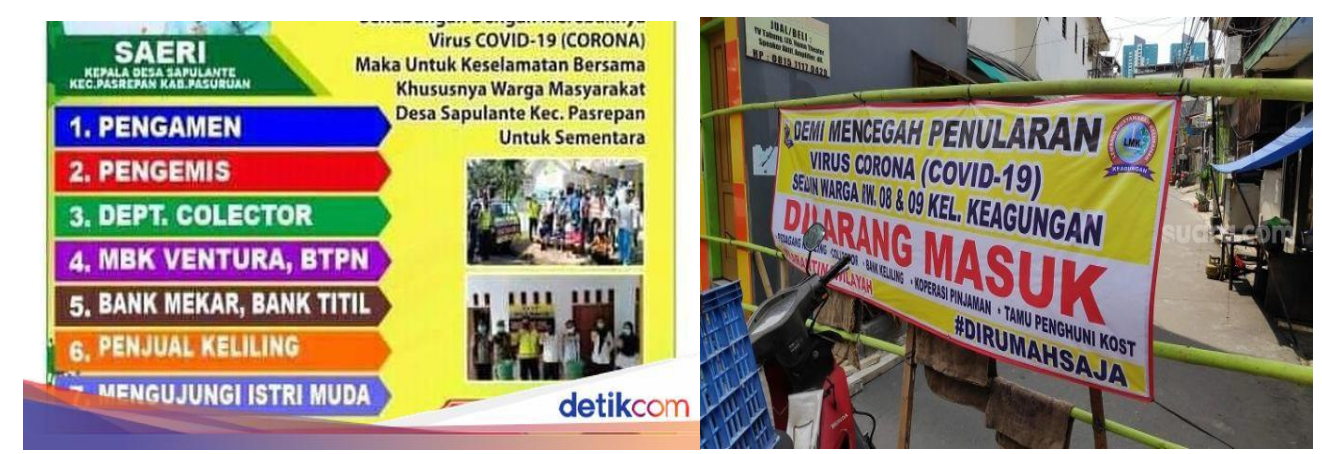

Gambar 1. Fenomena lembaga keuangan mikro dimasa pandemi

Gambar diatas menjelaskan bahwa begitu besar dampak pandemi ini terhadap lembaga keuangan mikro. Hal tersebut mungkin karena ketakutan terhadap penularan covid-19 sehingga warga bersatu dan didukung oleh perangkat desa membuat aturan untuk melarang lembaga keuangan mikro, leasing bahkan sampai pedagang keliling dilarang memasuki wilayah tersebut. Ini juga berdampak langsung pada koperasi dengan sistem bulanan (normal) yang seharusnya tidak masuk dalam kategori tersebut. Sehingga pendapatan koperasi akan menurun drastis mengingat produk utamanya adalah simpan pinjam. Hal senada juga dialami doleh BPR (Bank Perkreditan Rakyat), dimasa pandemi ini kinerjanya juga mengalami penurunan karena statement dari presiden yang ditelan mentah-mentah. Dikuti dari www.cnbcindonesia.com bulan maret lalu bahwa presiden memberikan kelonggaran (relaksasi) kredit bagi nasabah yang terdampak pandemi covid-19. Hal ini yang akhirnya banyak nasabah berbondong-bondong datang ke bank termasuk BPR untuk meminta keringanan dengan dasar instruksi dari presiden. Hal ini juga membuat katyawan BPR kalang kabut untuk memberikan penjelasan terkait instruksi tersebut. Sampai akhirnya Otoritas Jasa Keuangan (OJK) telah menerbitkan Peraturan OJK No. 11/POJK.03/2020 tentang Stimulus Perekonomian Nasional. POJK itu menjadi landasan bagi bank maupun perusahaan pembiayaan untuk melakukan relaksasi pinjaman bagi debitur UMKM penerima kredit atau pembiayaan. Hal ini ditegaskan lagi oleh ketua AAPI (asosiasi perusahaan pembiayaan indonesia) bahwa yang mendapatkan kebijakan relaksasi hanya nasabah yang terkena dampak langsung dari pandemi ini dan tata cara 
restrukturisasi kredit bisa dilakukan secara online mulai 30 maret 2020 (www.mediaindonesia.com)

Karyawan BPR harus menyesuaiakan diri terhadap kondisi yang bisa dikatakan masuk dalam masa sulit dlam melakukan penagihan. Kemampuan individu untukmenyesuaikan diri atau mengelola diri terhadap perubahan dalam pekerjaannya disebut dengan perilaku kerja adaptif (Allworth \& Hesketh, 1999). Pulakos, Arad, Donovan, dan Plamondon (2000), menyusun sebuah taksonomi sebagai kerangka untuk menggambarkan mengenai perilaku kerja adapatif. Taksonomi ini terdiri dari 8 (delapan) dimensi, yaitu: (1) kemampuan memecahkan masalah secara kreatif; (2) kemampuan mengatasi situasi kerja yang tidak menentu; (3) kemampuan mempelajari tugas, teknologi, dan prosedur baru; (4) kemampuan adaptasi interpersonal; (5) kemampuan adaptasi budaya; (6) kemampuan adaptasi fisik; (7) kemampuan mengatasi stres kerja; (8) kemampuan mengatasi siuasi kritis. Berdasarkan paparan ini bisa disimpulkan bahwa adaptasi karyawan lembaga keuangan mikro dimasa pandemi bisa dikategorikan kedalam 4 kegiatan utama yaitu membangun komunikasi dengan ansabah, membiasakan diri dengan kondisi baru, bersosialisasi dan bergaul dengan masyarakat, terus bergerak memenuhi target. Ke empat point ini merupakan strategi utama yang harus dijalankan karyawan agar tetap bisa berkontribusi terhadap perusahaannya. Jika ini dapat diimplementasikan dengan baik maka operasionalisasi lembaga keuangan mikro tetap terjaga dan akan mampu bertahan dimasa pandemi ini. Berdasarkan pemaparan diatas maka penelitian ini dilakukan untuk menjawab pertanyaan bagaimana perilaku karyawan lembaga keuangan mikro dimasa pandemi.

\section{METODE PENELITIAN}

Penelitian ini menggunakan metode kualitatif untuk menyelidiki hal-hal yang terdapat dalam lingkungan alami (natural settings), dan mencoba menginterpretasi fenomena tersebut. Penelitian kualitatif diartikan sebagai kegiatan-kegiatan terencana, mencakup seperangkat praktek penaf-siran yang memudahkan dunia partisipan dan informan dapat terlihat. Terdapat lima pendekatan metodologis dalam penelitian kualitatif, yaitu: biografi, fenomenologi, grounded theory, studi kasus, dan etnografi. Perspektif penelitian yang digunakan sesuai dengan tujuan 
penelitian ini, yaitu; fenome-nologi yang mengkaji mengenai fenomena perilaku karyawan lembaga keuangan mikro khususnya koperasi dan BPR (Bank Perkreditan rakyat) terkait dengan kebijakan pemerintah baik tentang relaksasi dan strukturisasi kredit maupun kebijakan physical/social distancing yang tentunya berdampak pada sistem dan pola dalam pekerjaannya (Denzin \& Lincoln, 2000; Creswell, 2007).

Penelitian ini menggunakan dua partisipan dimana mereka adalah dua orang pimpinan Lembaga Keuangan Mikro. Informan dipilih dengan teknik purposive dengan kriteria pada level top manajemen karena dianggap sebagai pengambil keputusan untuk menentukan kebijakan karyawan dalam menangani nasabah dimasa pandemi. Berdasarkan kriteria tersebut diputuskan untuk memilih dua orang pimpinan dimana yang satu adalah pimpinan koperasi dan satu lagi adalah pimpinan cabang Bank Perkreditan Rakyat (BPR). Sumber data yang digunakan adalah data primer yang diperoleh dari wawancara langsung melalui telepon karena tetap harus patuh dengan protocol covid. Satu partisipan bisa sampai 3x telepon karena peneliti menyesuaikan ketersediaan waktu dari partisipan. Pengambilan data dilakukan bulan juni dengan alasan pada bulan tersebut tepat genap 3 bulan setelah instruksi relaksasi kredit dikeluarkan oleh pemerintah sehingga sesuai dengan tujuan penelitian.

Analisis data dimungkinkan terjadi dalam perspektif intersubyektif antara peneliti dengan partisipan dengan "menunda" bias-bias atau prasangka peneliti terhadap fenonema yang sedang dipelajarinya sehingga fenomena yang diteliti tampil sebagaimana adanya (appears or presents it self). Misalnya, Moustakas (1994) mengidentifikasi lima tahapan utama dalam analisis data fenomenologis (dilakukan iteratif), berikut ini:

1) Membuat daftar ekspresi-ekspresi dari jawaban atau respon partisipan dengan menunda prasangka peneliti (bracketing) untuk memungkin ekspresiekspresi tersebut tampil sebagaimana adanya. Setiap ekspresi pengalaman hidup partisipan diperlakukan secara sama (horizonalization). Membuat

2) Kedua, reduksi dan eliminasi ekspresiekspresi tersebut mengacu pada pertanyaan: apakah eskpresi tersebut merupakan esensi dari pengalaman partisipan dan apakah ekspresi-ekspresi dapat dikelompokkan untuk diberi 
label dan tema. Ekspresiekspresi yang tidak jelas, pengulangan dan tumpang tindih direduksi dan dieliminasi. Kemudian ekspresi-ekspresi bermakna diberi label dan tema.

3) Ketiga, membuat klaster dan menuliskan tema terhadap ekspresi-ekspresi yang konsisten, tidak berubah dan memperlihatkan kesamaan. Klaster dan pemberian label terhadap ekspresi-ekspresi tersebut merupakan tema inti pengalaman hidup partisipan.

4) Keempat, melakukan validasi terhadap ekspresi-ekspresi, labeling terhadap ekspresi dan tema dengan cara (1) apakah ekspresi-ekspresi tesebut eksplisit ada pada transkip wawancara atau catatan harian partisipan; (2) apabila ekspresi-ekspresi tersebut tidak.

\section{PEMBAHASAN}

Penelitian ini menghasilkan beberapa temuan terkait perilaku karyawan lembaga keuangan mikro khususnya koperasi dan bank perkreditan rakyat (BPR) dimasa pandemi covid-19. Sebelum masuk kepenjelasan temuan, berikut ini akan disajikan profil singkat dari dua partisipan dan tema-tema utama yang muncul dalam analisis data.

\section{Partisipan SLS}

SLS merupakan salah satu tokoh masyarakat terkemuka dikabupaten madiun. Memiliki pengalaman bekerja di lembaga keuangan mikro yaitu BPR selama lebih dari 15 tahun dengan posisi account officer yaitu mengurusi bagian kredit mulai dari mencari nasabah hingga melakukan pembinaan jika terjadi kredit macet. Latar belakang pendidikan beliau adalah sarjana sehingga kapasitas dalam pola fikir dan tindakan tidak perlu diragukan lagi. Ditunjang dengan status tokoh masyarakat di satu wilayah yang mempermudah dalam melakukan pekerjaan. Secara rinci kegiatan beliau ketika di BPR adalah mencari nasabah yang mau meminjam, kemudian melakukan survey dan analisa kredit, dan membuat proposal kredit yang diajukan ke pimpinan untuk mendapatkan persetujuan kemudian melakukan realisasi kredit, dan pengawasan kredit selama 6 bulan sejak kredit dicairkan kepada nasabah. Selama bekerja di BPR beliau telah merealisasi kredit lebih dari 300 nasabah dengan nilai outstanding kredit sebesar lebih dari 1 milyar. Ini merupakan jumlah yang 
sangat besar. Pada tahun 2012 beliau memilih resign dari BPR kemudian beliau dipercaya untuk memimpin koperasi di Ngawi yang baru berdiri 2 tahun dan membawahi 6 karyawan. Pengalaman beliau selama puluhan tahun sebagai karyawan di BPR tentu sebagai bekal beliau memimpin dikoperasi tersebut. Tugas beliau di koperai tersebut adalah memeriksa pengajuan analisis kredit dari karyawan kemudian melakukan persetujuan. Pada tahun 2017 aset koperasi tersebut sudah lebih dari 5 milyar. Ini menunjukkan prestasi kerja yang cukup baik.

\section{Partisipan WD}

WD adalah seorang perempuan berusia 40 tahun dan merupakan teman dari SLS pada saat bekerja di BPR. karakter yang dimiliki WD adalah semangat kerja dan disiplin yang tinggi serta tanggung jawab dalam melaksanakan setiap pekerjaan yang memang merupakan bagiannya. Latar belakang pendidikan beliau adalah sarjana sehingga kompetensi akademik tidak perlu ditagukan lagi. Beliau bekerja di BPR lebih dari 10 tahun. Sebagai karyawan BPR beliau memiliki pengalaman di beberapa posisi yaitu sebagai CS (customer service), Admin kredit, Teller, BCS (Based Credit System) dan posisi back office lainnya. Memang pada saat di BPR ada aturan bahwa setiap karyawan harus selalu siap jika sewaktu-waktu di rolling posisi, sehingga karyawan bisa belajar hal baru dan pengetahuan tentang pekerjaan bertambah. Saat ini beliau menjabat sebagai kepala cabang BPR di pacitan jawa timur. Sudah lebih dari 2 tahun beliau memegang jabatan ini dan kinerja beliau juga cukup bagus. Beliau membawahi lebih dari 10 karyawan. Tugas beliau adalah memberikan persetujuan proposal kredit yang diajukan oleh karyawan dan bertanggung jawab pada keputusannya tersebut. Beliau tnggal dimadiun sedangkan kantornya di pacitan sehingga jarak tempuh lebih dari $100 \mathrm{~km}$. Ini yang membuat beliau memutuskan untuk selama hari efektif kerja (senin-jumat) berada di pacitan dan pulang kemadiun seminggu sekali.

\section{Tema-tema perilaku adaptif}

Perilaku adaptif yang dikaji dalam penelitian ini meliputi semua aktivitas karyawan yang dilakukan pada saat pandemi terutama setelah keluarnya instruksi dari pemerintah tentang relaksasi kredit. Hal tersebut membawa dampak bagi 
perilaku nasabah dalam membayar angsuran disisi lain memang kebanyakan kondisi usaha nasabah juga menurun. Namun karyawan tetap harus memenuhi target yang ditetapkan oleh kantornya. Oleh karenanya sebagai pimpinan harus membuat kebijakan dan menginstruksikan kepada bawahannya untuk melaksanakan aturan tersebut. Sehingga upaya adaptif perlu dilakukan karyawan dan merujuk pada 4 (empat) hal yaitu bagaimana karyawan tetap membangun komunikasi dengan nasabah, membiasakan diri dengan keadaan baru, sosialisasi dan pergaulan dengan massyarakat, dan tetap bergerak untuk memenuhi target.

\section{Membangun Komunikasi dengan Nasabah}

Komunikasi merupakan hal yang sangat fundamental digunakan untuk menjelaskan kepada nasabah supaya mengerti tentang aturan dan syarat pengajuan restrukturisasi kredit dimasa pandemi. kedua partisipan melakukan komunikasi intens pada nasabah yang datang mengajukan keringanan maupun bagi nasabah yang sengaja tidak mau datang kekantor untuk membayar angsuran. Meskipun dalam realitanya pasti menghadapi banyak kendala karena memang kondisi dan keadaan dari usaha nasabah dimasa pandemi ini juga menurun.

Saya setiap hari melakukan komunikasi dengan nasabah, untuk selalu mengingatkan akan tanggung jawabnya membayar angsuran. melalui telfon langsung, whatsup dan kadang terpaksa saya juga datangi langsung jika karyawan membutuhkan bantuan. Saya juga harus memberikan penjelasan kepada nasabah deposito bahwasanya dimasa pandemi ini karena pendapatan sedikit mengalami penurunan maka untuk bunga deposito juga dikurangi sampai pandemi ini selesai dan kembali normal. Ini saya lakukan untuk menjaga kestabilan kinerja keuangan dan keberlanjutan dari koperasi ini.(SLS.9-06-2020)

Kutipan diatas menjelaskan bahwa partisipan memang berupaya maksimal dimasa pandemi ini untuk tetap melakukan komunikasi dengan nasabah. Hal senada juga diceritakan oleh parisipan WD sebagai berikut.

Kalau komunikasi dengan nasabah setiap hari saya lakukan mas, bahkan saya menitip pesan juga pada seluruh karyawan untuk melakukan hal yang sama. Banyak nasabah yang bandel yang sengaja tidak mau membayar angsuran karena mengikuti instruksi dari presiden. Jadi saya berupaya keras menjaskan bahwa restrukturisasi itu ada persyaratan dan ketentuannya. Klo memang usaha mereka terdampak langsung karena pendemi ini bisa dimaklumi, lah ini ada yang sengaja ikut-ikutan memanfaatkan moment ini untuk "ngeblong" alias tidak mengangsur (WD.11-06-2020)

Berdasarkan penjelasan kedua partisipan diatas dapat disimpulkan bahwa di masa pandemi ini kondisinya sangat berbeda dengan biasanya. Dimana mereka harus berupaya keras setiap hari membangun komunikasi pada nasabah kredit untuk tidak lepas dari tanggung jawabnya membayar angsuran. penjelasan yang 

bisa ikut prihatin karena jumlah bunga yang diterima tidak bisa penuh. Hal ini tidak mudah karena jika nasabah tidak bisa percaya dengan penjelasan tersebut terutama nasabah deposan maka dia akan memindahkan uangnya ke koperasi lain. Untuk itu strategi komunikasi ini perlu dipandang sebagai perilaku yang adaptif bagi karyawan untuk mengatasi persoalan target di masa pandemi.

\section{Membiasakan diri dengan kondisi baru}

Merupakan perilaku membiasakan diri pada hal yang positif. Pasa bulan april-meri kemarin banyak pemerintah mengeluarkan kebijakan sosial dan physical distancing dimana melarang kegiatan yang mengundang kerumunan masa. Beberapa instansi dan perusahaan swasta menerapkan cara kerja WFH (work from home) dengan daring (online) dan juga pengaturan jadwal kerja secara bergantian. Misalnya karyawan hanya masuk seminggu sekali dikantor selebihnya WFH atau ada pula yang satu hari masuk dan satu hari libur. Bagi instansi dan perusahaan swasta yang menerapkan aturan harus masuk kantor maka jam kerja wajib disesuaikan dan menerapkan protocol covid seperti memakai masker, sarung tangan dan menyediakan sarana untuk cuci tangan bagi karyawan maupun masyakarat. Tidak terkecuali BPR dan koperasi yang menerapkan protocol covid tersebut karena mereka harus masuk kanto seperti biasanya namun jam kerja yang disesuaikan.

Kedua partisipan ini harus memberikan arahan kepada bawahannya untuk selalu menerapkan protocol covid dalam bertugas termasuk menjaga jarak dan sebagainya. Sehingga karyawan mampu beradaptasi dengan kondisi yang baru dengan pola bekerja yang juga harus menyesuaikan.

Banyak jalan menuju lokasi nasabah ditutup karena aturan desa setempat yang pedagang keliling, bank harian, debt collector dan sebagainya masuk ke lokasi mereka dengan dali memutus mata rantai covid-19. Jadi karyawan saya suruh tidak memakai seragam dan sepatu bila berkunjung kenasabah kayak orang main saja tapi disana melakukan pembinaan pelan-pelan kenasabah. Ini merupakan upaya adaptif dari karyawan dimasa pandemi ini. (SLS.9-06-2020).

Kutipan diatas adalah adaptasi keryawan koperasi dimasa pandemi dengan cara yang unik dan pantang menyerah karena memang sudah menjadi tanggung jawabnya. Demikian pula pada partisipan yang satulagi adalah sebagai berikut. 
Setiap karyawan harus membiasakan diri sebelum masuk kantor wajib mencuci tangan dan menggunakan masker. Untuk kegiatan breffing karyawan setiap pagi tetap dilakukan dengan menjaga jarak dan tanpa berjabat tangan. Karyawan juga harus beradaptasi dengan jam kerja yang lebih pendek sehingga harus berupaya keras dalam melakukan penagihan karena menjadi fokus utama dimasa pandemi daripada melakukan realisasi kredit. (WD.11-06-2020).

Berdasarkan dua kutipan diatas disepakati bahwa kedua partisipan memiliki cara unik yang berbeda untuk beradaptasi dimasa pandemi ini. Kebijakan pemerintah dimasa pandemi ini telah merubah pola kerja dan kebiasaan dari bankbank umum dimana jam kerja mereka diperpendek dan juga pengaturan tata ruang didalam kantor termasuk kursi tunggu untuk nasabah yang jaraknya juga diatur. Demikian juga pada lembaga keuangan mikro seperti BPR dan koperasi juga melakukan hal yang sama. Namun sedikit berbeda karena meskipun karyawan BPR maupun koperasi memiliki jam kerja pendek tetapi target mereka juga tetap besar hanya saja lebih ditekankan pada proses penagihan untuk mengejar target pendapatan karena memang itu sumber pendapatan terbesarnya.

\section{Bersosialisasi dan Bergaul dengan Masyarakat}

Merupakan kemampuan karyawan lembaga keuangan mikro untuk bergaul dengan masyarakat. Mereka harus merasa dekat dengan masyarakat karena bisa jadi mereka adalah calon nasabah potensial. Kemampuan ini sebenarnya sudah ditunjukkan oleh lembaga keuangan mikro sejak dulu melalui strateginya "jemput bola" hanya saja karena persaingan saat ini semakin ketat dan teknologi komunikasi semakin maju maka untuk alasan efektivitas sudah mulai dikurangi. Namun kedepan sepertinya cara ini perlu dihidupkan lagi karena terbukti ampuh dalam menggaet calon nasabah baru maupun pembinaan nasabah lama.

\footnotetext{
Ada nasabah yang bahkan jika punya hajat "sunatan" anaknya ataupun resepsi pernikahan saya selalu diundang. Mungkin karena saya sudah menjadi bagian dari perjalanan usahanya. Kalau ada waktu pasti saya datangi karena selain membuktikan bahwa kami memang dekat dengan mereka, moment ini juga bisa saya manfaatkan untuk memperkenalkan diri dengan kehadiran perusahaan kami di wilayah mereka. Banyak dari mereka setelah itu menghubungi kami untuk kredit maupun menabung ditempat kami. (SLS.9-06-2020)
}

Hal Senada juga dikatakan oleh partisipan WD dalam menyikapi pentingnya karyawan untuk selalu dekat dengan masyarakat terutama diwilayah operasional mereka. 
Pimpinan kami memberikan teladan agar setiap karyawan termasuk jajaran manajer dibawahnya memiliki rasa empati tinggi terhadap karyawan lain jika ada yang terkena musibah. Termasuk mengunjungi nasabah jika diundang dalam sebauh acara. Cuman dimasa pandemi ini undangan tersebut tidak ada karena kebijakan dari pemerintah sehingga karyawan bermasyarakat bermula dari warung, karena disitulah tempat penyebaran segala informasi didesa. Dan kebiasaan petani, pedagang dan masyarakat sekitar memang sering "marung" setelah selesai bekerja. (WD.11-06-2020)

Strategi untuk mendekati masyarakat dan bisa bergaul dengan mereka secara dekat juga menjadi prioritas kebijakan perusahaan di pusat. Aturan rekruitmen karyawan baru wajib berasal dari wilayah operasional yang baru. Ini untuk mempermudah dalam segi promosi supaya lebih mengena.

Mayoritas yang bekerja dikantor cabang adalah orang-orang baru yang berasal dari wilayah sini. Sedangkan untuk posisi pimpinan cabang dan manajer diambilkan dari pusat yang tempat tinggalnya disekitar kantor pusat. Sehingga kami harus berkolaborasi untuk menyentuh masyarakat disekitar sini setidaknya untuk mengenalkan kehadiran peusahaan kita dengn harapan mereka tau dan mau kredit serta menabung disini. (WD.11-06-2020)

Berdasarkan keterangan diatas disimpulkan bahwa kuncil keberhasilan lembaga keuangan mikro adalah pada kemampuannya dalam bermasyarakat. Mengenal masyarakat serta mengetahui kebutuhan mereka dengan jelas. Ini sebagai modal untuk menciptakan produk baru sesuai dengan kebutuhan mereka dan melayani mereka sesuai dengan harapan kalau bisa malah lebih dari yang mereka ekspektasikan. Terlebih lagi dimasa pandemi sekarang ini tentu banyak dari mereka yang membutuhkan pinjaman lagi untuk memulai usahanya namun dengan skema yang sesuai kemampuan mereka maka BPR dan koperasi harus berfikir bagaimana supaya bisa melayani mereka tanpa merugikan disatu pihak.

\section{Terus bergerak memenuhi target}

Karyawan di lembaga keuangan mikro khususnya BPR dan koperasi tidak asing lagi dengan istilah "jemput bola" yaitu mereka mendatangi nasabah untuk menawarkan produk dan melakukan pembinaan pada nasabah lama. Medan terjal dan jalanan yang becek serta belum diaspal menjadi hal yang biasa dilalui setiap hari. Begitu ada informasi nasabah yang potensial maka karyawan mendatangi lokasi tersebut gidak peduli jauh atau dekat. Bergerak cepat merupakan salah satu cara untuk memenangkan persaingan karena mereka sadar bahwa pemain di sektor mikro bukan hanya mereka saja. Ada bank umum konvensional seperti BRI yang sudah tidak asing lagi dikalangan masyarakat pedesaan. Namun dari karyawan yakin tidak semua calon nasabah mau datang kekantor untuk kredit karena 
kesibukan mereka yang tidak bisa ditinggalkan, nah disinilah peluang lembaga keuangan mikro bisa masuk dan menawarkan produknya.

Nasabah kami sebagian besar petani yang tinggal dipedesaan dengan akses jalan makadam atau aspal batu. Itu pangsa pasar yang masih bisa kami layani sehingga mau tidak mau kami tetap harus kesana untuk menjemput peluang. Dimasa pandemi ini tantangannya adalah melakukan penagihan di wilayah tersebut karena spekulasi bahwa belum tentu jika sampai disana nasabah mau membayar padahal kami juga membutuhkan bensin untuk kesana. Disisi lain aturan desa yang melarang bank harian untuk berkunjung kesana meskipun sebenarnya mereka tahu bahwa kita bukan bank harian. (SLS.9-06-2020)

Kutipan diatas menyimpulkan bahwa pada masa pandemi ini serba sulit dalam melakukan pergerakan ke nasabah. Karena jarak yang jauh dan medan yang sulit disamping itu belum tentu juga nasabah mau membayar. namun mereka tetap harus kelokasi nasabah karena sudah menjadi tanggung jawab karyawan meskipun intensitas waktunya dikurangi.keseluruhan proses tahapan tadi dapat digambarkan seperti dibawah ini.

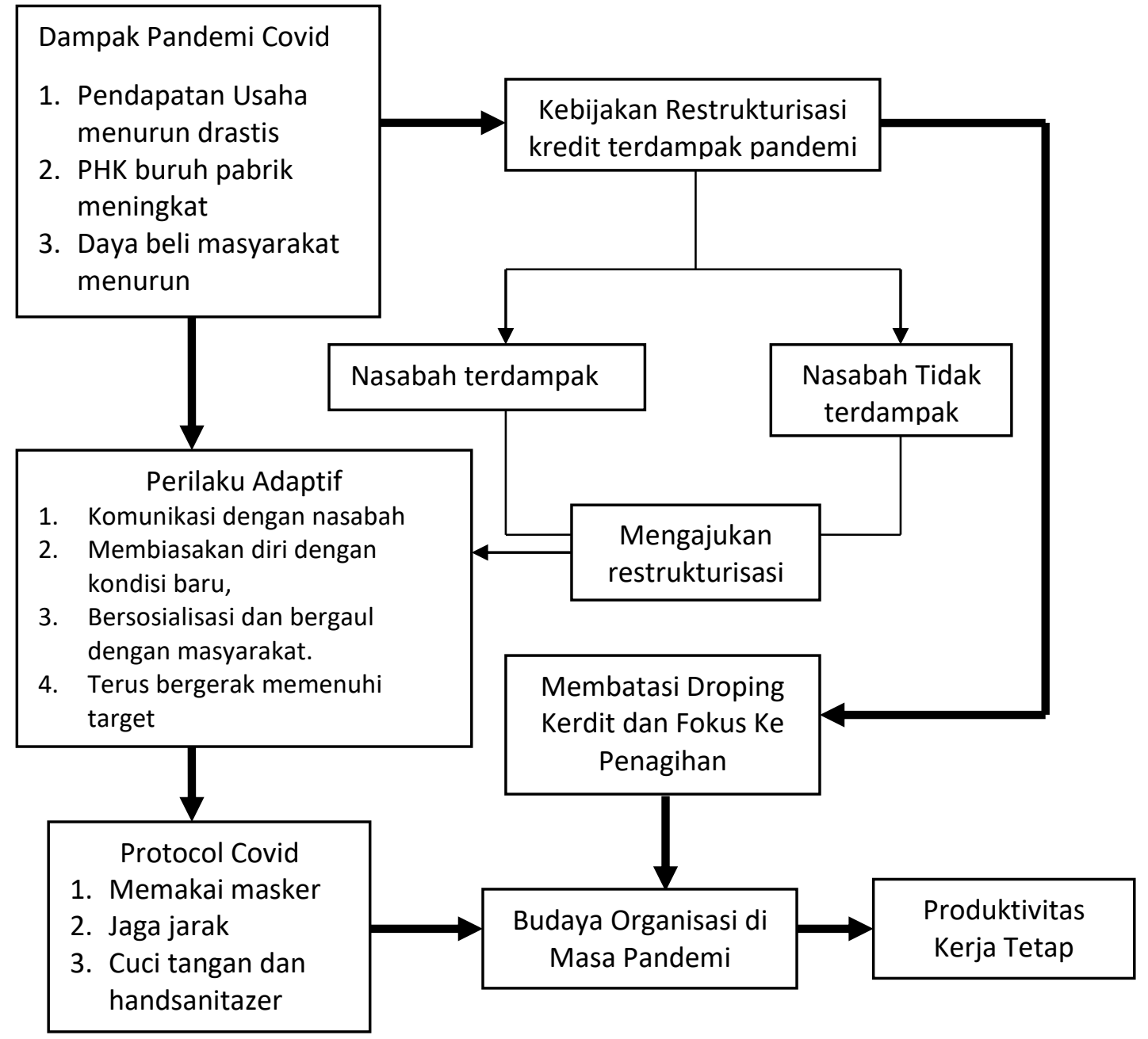

Gambar 2. Kerangka konseptual penelitian 


\section{DISKUSI}

Berdasarkan hasil analisis diatas terdapat 4 tema yang terkait dengan perilaku karyawan lembaga keuangan mikro khususnya BPR dan koperasi. Membangun komunikasi dengan nasabah, membiasakan diri dengan kodisi baru, bersosialisasi dan bergaul dengan masyarakat, Terus bergerak memenuhi target. Komunikasi merupakan faktor yang menentukan bagi kesuksesan sebuah organisasi. Komunikasi disini bersifat internal yaitu antar anggota dalam organisasi termasuk dengan atasan dan juga komunikasi yang dibangun dengan nasabah. Dalam penelitian ini partisipan melakukan komunikasi secara intens kepada nasabah untuk menjelaskan aturan kebijakan pemerintah tentang restrukturisasi kredit. Jadi lebih cenderung kmunikasi internal namun muaranya keberhasilan komunikasi yang dibangun ini juga merupakan cara untuk beradaptasi dimasa pandemi agar kinernya tetap terjaga. Bagaimanapun juga komunikasi baik internal maupun eksternal itu sangat dibutuhkan untuk meningkatkan kinerja karyawan dan keberlanjutan perusahaan itu sendiri. Pinontoan (2013) menyimpulkan bahwa kualitas komunikasi dari karyawan berpengaruh signifikan terhadap loyalitas nasabah Bank Mandiri Cabang Manado. Artinya penting menjaga komunikasi dengan nasabah dimasa pandemi ini nasabah tidak lepas dan berpindah kelain bank untuk itu karyawan perlu dibekali informasi terkait kebijakan Pemerintah dimasa pandemi ini dengan baik.

Partisipan juga membiasakan diri untuk menjaga pola hidup bersih terutama dimasa pandemi ini. dimana setiap kantor wajib menyediakan sarana untuk cuci tangan dengan sabun, menyediakan handsanitazer dan sarung tangan. Bagi karyawan dan nasabah yang memasuki kantor wajib dicek suhu terlebih dahulu jika normal maka baru diijinkan masuk. Ini merupakan protocol wajib yang dijalankan selama musim pandemi dan sudah menjadi kebiasaan para karyawan lembaga keuangan mikro khususnya BPR dan koperasi. Kedepan jika ini terus diberlakukan maka bisa jadi akan masuk sebagai salah satu budaya organisasi lembaga keuangan mikro. Budaya organisasi yang di pahami oleh setiap karyawan untuk membiasakan perilaku hidup bersih diharapkan bisa menjaga kinerja karyawan sehingga produktivitas kerjanya dimasa pandemi tetap terjaga. Karena karyawan BPR maupun koperasi tetap harus masuk dan tidak bisa melakukan WFH (work from 

berpengaruh positif dan signifikan terhadap produktivitas kerja karyawan pada kantor PT Bank Mestika Dharma, Tbk. Cabang Pematangsiantar. Jadi sudah saatnya lembaga keuangan mikro menerapkan pola pola hidup bersih dengan protocol cobid dimasa pandemi karena karyawan mereka sering bertemu dengan nasabah yang notabene paling banyak di wilayah pasar tradisional dan pusat kerumunan lainnya.

Perilaku bersosialisasi dan bergaul dengan masyarakat, merupakan cara partisipan untuk membina hubungan baik dengan nasabah maupun masyarakat. Koentjaraningrat (2002) mendefinisikan mengenai masyarakat secara khusus yaitu kesatuan hidup manusia yang berinteraksi menurut suatu sistem adat istiadat tertentu yang bersifat kontinyu, dan yang terikat oleh suatu rasa identitas bersama. menurut Gerungan (1978) bahwa "Pada hakikatnya manusia adalah makhluk sosial". Manusia harus bisa hidup bersama dengan individu lain, sehingga terjadi situasi sosial. Berdasarkan dua definisi tersebut bisa disimpulkan bahwa perilaku sosial bermasyarakat adalah cara orang untuk berinteraksi dengan lingkungan di masyarakat dengan saling menghargai hingga terbentuk sebuah pola positif yang mencirikan adab lingkungan tersebut. Karyawan BPR dan Koperasi sudah memiliki pengalaman interaksi dengan masyarakat sejak dulu karena mereka umumnya menggunakan strategi "jemput bola" kepada nasabah. Membangun interasksi dengan perangkat desa sebelum memasuki suatu wilayah (Wihara dan Haqqi, 2017).

Karyawan harus terus bergerak untuk bisa memenuhi target dengan berkunjung ke nasabah untuk melakukan pembinaan. Medan yang terjal dan jalan yang belum beraspal membuat tantangan tersendiri bagi setiap karyawan. Dan hal tersebut memang sudah biasa dilakukan setiap harinya. Hanya saja di selama pandemi ini memang intensitas ke nasabah dikurangi karena ada kebijakan sosial dan physical distancing. Beberapa wilayah desa sengaja melarang orang lain diluar wilayah tersebut berkunjung ke situ sehingga ini semakin menyulitkan karyawan untuk melakukan pembinaan. Namun mereka tetap bergerak menuju nasabah dengan cara merubah penampilan yaitu tidak memakai seragam dan sepatu supaya bisa masuk ke wilayah tersebut. Strategi jemput bola dengan mendatangi nasabah ini selain untuk melakukan pembinaan juga dimanfaatkan untuk menawarkan produk 
lain seperti tabungan dan deposito, dan hasilnya cukup efektif karena sebagian besar nasabah petani hampir tidak memiliki waktu untuk datang ke bank sehingga untuk menabung atau membayar angsuran karyawan mendatangainya. Penelitian Umam dan Rufaida (2019) menyimpulkan bahwa pelayanan jemput bola kepada nasabah dipandang efektif karena berpengaruh signifikan terhadap motivasi nasabah untuk menabung di BMT NU Camplong Madura. Meskipun dimusim pandemi ini partisipan mengatakan bahwa tidak ada penambahan signifikan bagi nasabah penabung namun ada beberapa nasabah kredit yang menabung untuk berjaga-jaga membayar angsuran sewaktu-waktu.

\section{KESIMPULAN}

Temuan hasil analisis data dan interpretasi yang dilakukan diatas untuk menjawab tiga pertanyaan penelitian. Yang pertama terkait perilaku adaptif karyawan dalam menjelaskan kebijakan restrukturisasi kredit dari pemerinta. Dimana partisipan telah berupaya maksimal untuk menjelaskan secara detail kenasabah tentang ketentuan dan persyaratan. Namun beberapa nasabah memang ada yang sengaja tidak membayar karena memanfaatkan momentum bahkan ada yang memang karakternya sudah tidak bagus. Restrukturisasi kredit ditujukan bagi nasabah yang terdampak langsung pandemi covid-19 sehingga pendapatan usahanya menurun, atau usahanya tidak jalan, dan juga bagi nasabah yang terkena PHK (pemutusan hubungan kerja). Semua ini dibuktikan dengan surat keterangan yang bisa dipertanggungjawabkan. Yang kedua, lembaga keuangan mikro juga mengedukasi nasabah terkait kebijakan social dan physical distancing dengan cara menerapkan protocol covid seperti mewajibkan pakai masker, cuci tangan dan jaga jarak ketika memasuki kantor kebijakan ini juga berlaku untuk karyawan mereka. Cek suhu tubuh juga dilakukan untuk mengantisipasi terjadinya hal yang tidak diinginkan.

\section{DAFTAR PUSTAKA}

Allworth, E., \& Hesketh, B. (1999). Construct-oriented biodata: Capturing changerelated and contextually relevant future performance. International Journal of Selection and Assessment, 7 (2), 97-111

Astuti, Y, R . 2016. Penerapan Prinsip Kehati-hatian dalam Penyaluran Pembiayaan dan Kredit pada lembaga keuangan Mikro (studi multi situs pada BMT 
Hasanah mlarak dan BRI unit mlarak, Ponorogo). Jurnal Al Tijarah Vol 2 No 1

ISSN 2460-4089 Universitas Darussalam Gontor

Creswell J.W . 2007. Qualitative Inquiry \& Research Design : Choosing among Five Approach. 2nd edn. California Sage

Denzin and Lincoln.2000. Handbook of Qualitative Research. London: Sage Publicati on

Enggana, Juli (2017) Pengaruh Budaya Organisasi dan Disiplin Kerja terhadap Produktivitas Kerja Karyawan pada PT. Bank Mestika Dharma, tbk. Cabang Pematangsiantar. Jurnal SULTANIST Vol 6 No.1 ISSN 2338-4328

Elizabeth B. Hurlock. 1978. Perkembangan Anak: Jakarta: Penerbit Erlangga.

Gerungan, W.A. 1978. Psychologi-sosial suatu ringkasan. Jakarta: PT Eresco.

Kirk, Samuel., Gallagher, James \& Coleman, Mary Ruth. (2015). ). Educating exceptional children, (14th ed). United States of America: Cencange Learning.

Koentjaraningrat. 2002. Pengantar Ilmu Antropologi. PT. Rineka Cipta, Jakarta.

Moustakas, C. (1994). Phenomenological research methods. Thousand Oaks, CA: SAGE Publications.

Pinontoan, Wulan (2013) Pengaruh E-banking, kualitas pelayanan, kualitas komunikasi dan kepercayaan terhadap loyalitas nasabah pada PT. Bank Mandiri cabang manado. Jurnal emba vol 1 no 4 issn 2303-1174.

Pulakos, E. D., Schmitt, N., Dorsey, D. W., Arad, S., Hedge, J. W., \& Borman, W. C. (2002). Predicting adaptive performance: Further tests of a model of adaptability. Human Performance, 15 (4), 299-323.

Smith, D.D., \& Tyler, N.C. (2010). Introduction to Special Education. Canada: Pearson.

Tom O'Donoghue and Keith Punch Ed. (2003). Qualitative Educational Research In Action: Doing and reflecting London: Routledge Falmer Pub.

Umam, Muslihul dan Rufaida Rifki (2019) Motibasi Menabung Nasabah melalui Sistem Service Jemput Bola di BMT NU Camplong. Journal of social community Vol 4 No 1 ISSN 2502-9649.

Wihara, Dhiyan, S dan Haqqi, Rilla, I (2017). Implementasi Strategi Deferensiasi Bpr (Bank Perkreditan Rakyat) Untuk Menjaga Eksistensinya Terhadap Bank Umum Di Wilayah Kabupaten Madiun. Jurnal EKOMAKS Vol. 6 No.2 ISSN 2302-4747 Universitas Merdeka Madiun

Wulandari, Retno, D (tt) Strategi pengembangan perilaku adaptif anak tunagrahita Melalui model pembelajaran langsung. Pascasarjana Universitas Negeri Yogyakarta. Artikel tidak dipublikasi.

Yuniarti, Sari (2011) Strategi Adaptif Bank Perkreditan Rakyat Dalam Menghadapi Ekspansi Kredit Umkm Bank Umum Di Malang. Jurnal Keuangan Dan Perbankan Vol.15, No.3 Uniersitas Merdeka Malang

Undang-Undang No 10 Tahun 1998 Tentang Perbankan

Sumber Internet :

https:/ / www.cnbcindonesia.com/market/20200324131204-17-147248/cicilansederet-kredit-ditangguhkan-jokowi-ini-aturannya diakses pada tanggal 15-06-2020 https:/ / www.suara.com/bisnis/2020/04/04/135406/debt-collector-hingga-bankkeliling-dilarang-nagih-utang-ditengah-corona diakses pada tanggal 16-06-2020 